\title{
9 Divorce and Domestic Violence
}

FELICITY KAGANAS AND CHRISTINE PIPER

This book is about the ways in which divorce and divorce law and procedure have been constructed as problems requiring a legislative response. In that process the central themes which emerged have been those of marriage saving and child saving, linked by particular ideas about the risk of harm to children as a result of parental divorce. This chapter focuses on the introduction into that agreed story about divorce of an issue which has the potential to disrupt the coherence of the story and to challenge the ideal of the consensual and conflictfree divorce. That issue is domestic violence.

Amendments incorporated into the Family Law Act 1996 signified official acknowledgement of the problem of domestic violence and its persistence even after separation and divorce. Yet, we will argue, within the dominant talk about divorce there is no clear and agreed picture of the prevalence, nature and effects of domestic violence when relationships break down. The changing and elusive picture of domestic violence reflected in debates in the political arena has resulted in legislation that, despite its acceptance of the principle of protection, is short on detail as to how this principle is to be upheld. It does not indicate how important the principle of protection is relative to the other, potentially contradictory, objectives of the statute. Nor, aside from Part IV orders, does it put in place mechanisms for detecting violence or dealing with it within the divorce process. Essentially, it is left to those implementing the legislation to devise ways of protecting those at risk. However, there is no agreed picture of domestic violence apparent in professional practice relating to divorce either; diversity of views and differing priorities characterise the professional world as well as the political one. This, we think, has worrying implications. Professionals dealing, in the front line, with divorcing clients may underestimate the likelihood that any particular client is or has been experiencing abuse and may misinterpret the information verbal or otherwise - that a client gives. As a result, they may fail to adopt 


\section{Undercurrents of Divorce}

proactive strategies for detecting whether violence is an issue and to protect clients where it is.

This chapter seeks, first, to give some indication of the images of violence that the framers of the legislation were intending to address in the statute. We then consider the extent to which these images are sustained by the available research. Finally, we examine current professional practice in order to assess whether, in that sphere, there may be the potential to resolve the contradictions between the different stories about divorce told by politicians, and which underlie the statute, as well as the contradictions between the stories told by some politicians and those told by researchers.

\section{Writing Domestic Violence into the Script}

Domestic violence was written into the story about divorce via amendments to the Bill which eventually became sections $1(\mathrm{~d}), 7(12)$ and $9(7)$ (d) (read with paragraph 4 of schedule 1).' Section 1(d) states that all professionals involved in the process of divorce must 'have regard' to the principle that 'any risk to one of the parties to a marriage, and to any children, of violence from the other party should, so far as reasonably practicable be removed or diminished'. 2 Section 7(12)(a) supplies an exception to the extension of the nine month period of reflection and consideration by six months where there is a child of the family who is under 16 . The exception applies if there is an occupation or molestation order in force in favour of the applicant, or a child of the family, against the other party to the divorce application. Paragraph 4 of schedule 1 , read with section $9(7)$ (d) creates an exception to section 9(2) and enables the court to grant a divorce order even though financial arrangements have not been settled. Again this applies only to cases where a Part IV order is in force. It is also subject to the provisos that the applicant has made efforts to reach agreement which have been unsuccessful and that delay in making an order would be detrimental to the child or prejudicial to the applicant.

The debates, particularly around section $1(\mathrm{~d})$, reveal a clear difference of opinion among parliamentarians as to whether protection from violence or the other aims of the legislation, notably marriage and child saving, should be given priority. The Government ultimately accepted that 'the potential for domestic violence will be present for some at a number of points in the divorce and separation process, and that it is right ... to take that into account' (Mr 
Streeter, Hansard, HC 17 June 1996, col 601). Yet there was concern in Parliament that to focus on violence is, potentially, to jeopardise the marriage saving project or, at the very least, the conflict-reduction exercise thought to be so important for the children's welfare: 'An ouster order will effectively scotch the prospects for reconciliation or second thoughts'. ${ }^{3}$

Perhaps surprisingly, section 7(12) appears to have been relatively uncontentious and there is little clarification of the reasoning behind it to be gleaned from the parliamentary discussion. Mr Leigh, urging adoption of an amendment embodying an earlier version of section $7(12),{ }^{4}$ explained the need for an extended period in terms of the 'safeguards' provided in relation to children (Hansard, HC 24 April 1996, col 502). The extended period was, he said, designed to send the 'important message that, if there are children in a marriage, that should make a difference to the divorce process. In such circumstances, the parties should not think first of themselves but of the interests of the children' (ibid). He assured the Committee of the House that 'it could be shortened to one year" - but not less - if there is a clear case of domestic violence, with a court order' or if, in the view of the court, an extension would be detrimental to the children concerned (ibid). These, he said, 'are clearly special cases' but did not explain why an exception for domestic violence was appropriate. Nor did he explain why, if domestic violence justified dispensing with the extension to the minimum period, it did not justify an abridgement of it too.

It appears that the specified period for reflection and consideration was considered the minimum necessary to prevent 'quickie' divorces and to promote reconciliation or, failing that, to establish that the breakdown was irretrievable and to enable practical arrangements for the future to be made (see Hansard, HC 24 April, cols 504-505, 529; Law Commission, 1990, para 525). These objectives could not be compromised under any circumstances. Why the extended period in children cases was considered less sacrosanct is not entirely clear, nor is it clear whether the exemption for cases involving violence was for the benefit of women, children or both. However it is significant that mention was made of the detrimental effects on children of violence generally (Hansard, HC 24 April 1996, col 498), and in terms of diminution of parenting capacity (col 494) as well as the risk that violence may be transmitted from one generation to another (idem). Reference was also made to the need to avoid fomenting conflict (col 506). The aims of marriage saving and child saving, it seems, were foremost in the legislators' minds; aims that could not be displaced 


\section{Undercurrents of Divorce}

in cases of violence.' However the benefits to children of making their parents wait longer appear to be offset by the damage prolonged exposure to violence might cause, but only if there is evidence of violence sufficient to warrant a Part IV order.

The debates on amendments which were the precursors of section 1(d) reveal clearer but more polarised pictures of domestic violence. Those in favour of the provision that protection from violence should be a principle underlying the whole of the new divorce process clearly had a picture of the pervasive and dangerous influence of domestic violence: 'domestic violence is not just an issue of occupation of the family home and immediate protection from violence for families but one that should permeate the thinking of all those involved in the divorce process' (Ms Corston, Standing Committee E, 30 April 1996, cols 59-60; see also Mr Boateng, at col 55). It should not, said one member, be dealt with as 'an afterthought or appendage to the law' but should be 'integral' to deliberations about the legislation (Ms Hodge, Standing Committee E, 30 April 1996, col 77). In particular, attention was drawn in that sitting to the potential perils to victims of the information meeting, attendance at court, mediation and contact (Mr Boateng, cols 57-59; Ms Hodge, cols 76 and 78-79; Mr Tipping, cols 84-85).

However, not all those who contributed to the debates had such a picture of domestic violence, with a corresponding commitment to protection for abused women. Rather, the debates reveal an assumption on the part of some speakers that what is inimical about domestic violence is primarily the effect it might have - directly or indirectly - on children. Mr Brazier, for example, expressed his belief that the main form of domestic violence is child abuse and that is more likely to be perpetrated by stepfathers than by natural fathers, suggesting that children face greater dangers from their mothers' future relationships than from their natural fathers (Standing Committee E, 30 April, cols 72, 63 and 79-80, respectively). Accordingly, said another speaker, having asserted that women variously attract, provoke and perpetrate violence,' children might be no better off 'as a result of destroying such a household' because mothers move on to further abusive relationships (Mr Rowe, Standing Committee E, 30 April, cols 65-67). In the light of that, as Mr Brazier pointed out later, 'it is not helpful to encourage the raising of the issue of domestic violence if it has not already been raised' (col 106).

The disadvantages attendant upon such encouragement were, it seems, compounded by the assumed proclivity of those involved in divorce to fabricate 
allegations of violence (cols 94-95 and 104). In any event, the inclusion in the general principles of a provision dealing with domestic violence was regarded by some speakers as unnecessary (Mr Evans, Standing Committee E, 7 May 1996, col 115) and the amendment was at that stage rejected. What became section 1(d) was reintroduced at a later stage when attention was being focused on domestic violence in the context of other clauses in the Bill. :

\section{The Research Picture of Domestic Violence}

The different pictures of domestic violence which emerge from the parliamentary debates are in contrast to the increasingly clear picture presented by recent research. The evidence now available suggests that a significant proportion of women experience abuse from their spouses during marriage, that separation and divorce are particularly dangerous times for women and that those who experience such abuse find it very difficult to admit to that fact.

\section{Divorce is Dangerous}

As many as 1 in 3 divorces may involve domestic violence and this can be the starting point for divorce proceedings. Last year [Legal Aid] certificates issued for domestic violence injunctions within divorce proceedings numbered over 6,000 (Legal Aid Board Research Unit, 1996, p.44).

The figure of ' 1 in 3 ' quoted above refers to research conducted in the UK around 20 years ago (Borkowski et al, 1983). However the finding in that study that $20 \%$ of wives' divorce petitions used evidence of domestic violence to satisfy the behaviour ground was confirmed in a later one, which reported a comparable figure of $22 \%$ (Law Commission, 1990, appendix C). * At a more general level it is also now well documented that a significant proportion of women experience domestic violence at some time in their lives - and that their ex-partners are one of the main categories of perpetrators.' In a study by Rights of Women (Anderson, 1997), for example, nearly one third of the cases involved some form of violence after proceedings began (p.32)." There is, in addition, voluminous research on the extent of marital and separation violence from the other side of the Atlantic which yields similar evidence.' The cumulative effect of these research findings present a relatively clear picture of domestic violence: many women - across race and class - experience some form 


\section{Undercurrents of Divorce}

of violence and control at the hands of their husbands during marriage, after separation, or both. There is little doubt that separation and divorce are especially risky times.

\section{Reluctance to Tell}

There is also research evidence showing that those who have been at the receiving end of abuse do not always readily volunteer this information. Victims as well as abusers tend to minimise or deny violence: voluntary disclosure is relatively unusual (Pagelow, 1990, p.355). Researchers have advanced a number of possible explanations for this. First, to acknowledge violence by disclosing it, is to acknowledge that the relationship in which so much has been invested cannot continue. Disclosure may therefore signify too much personal loss for it to be psychologically possible." Moreover, while some victims may refrain from seeking help for fear of retaliation, others may still be emotionally bound to their partners; Ellis and DeKeseredy refer to the loyalty/love that victims often feel $(1997$, p.601). The possibility that victims do not disclose during the course of their relationships is significant on divorce: it means that there is no 'official' evidence in the form of court orders or criminal proceedings that abuse occurred. This, in turn, makes it less likely that the abuse will be discovered on divorce.

Secondly, even on divorce the victim/survivor may not expect to be believed or taken seriously (Astor, 1991, p.21). Thirdly, she may fear being labelled a failure - a misplaced sense of shame therefore inhibits disclosure (Mooney, 1993, p.60). Fourthly, she may have fears that she will lose her children (Morley, 1993). Fifthly, it may be difficult for her to redefine an intimate partner as an abuser, particularly if he is the father of her children (Mahoney, 1994, pp.74-75). Finally, she may not disclose because she does not conform to her own stereotypes of battered women (Fischer et al, 1993, pp.2140-2141; Kelly and Radford, 1990/1, p.40).

\section{Power and Control}

Many abusive relationships are characterised by a pattern of 'coercive control' involving 'an ongoing strategy of intimidation, isolation, and control that extends to all areas of a woman's life, including sexuality; material necessities; relations with family, children and friends; and work' (Stark, 1995, p.986)." As 
a result, the abused partner may agree out of fear (Mahoney, 1991; Kurz, 1996, p.137) or fatigue, to demands made by the abusing partner which are financially detrimental or potentially oppressive for herself or her children. In relation to the making of arrangements on divorce this can mean that the partner who has experienced longstanding intimidation and control may be unable to participate as an equal in informal dispute resolution procedures.

This makes attendance at mediation problematic though it is argued' that as long as mediation is voluntary, victims of abuse are adequately protected. However, research shows that an abused partner may agree to mediation even if she knows that it is voluntary and that, if she attends, this may prove detrimental to her. Hester et al point out:

It needs to be recognised that there are a number of different reasons why women who have experienced ongoing violence and abuse from male partners will agree to attend mediation. For instance, in their desperation to have services deal with the abusive man they will attend mediation; or they may feel they have to attend in order not to appear obstructive to the courts; or they feel it would be more beneficial to the children in the long term despite the dangers to them selves $(1997$, p.59).

Knowledge that domestic violence is not a rare phenomenon in the context of divorce, coupled with knowledge that spontaneous disclosure is not common and that the experience of violence can affect negotiating abilities, may provide the impetus for professionals to adopt procedures designed to facilitate disclosure. Failure to use such procedures can have far reaching consequences.

\section{A Risky Process}

\section{Family Law Act 1996}

Section 1(d) of the Act establishes the principle that professionals should seek to remove or reduce the risk of violence. There are a number of 'risky' stages of the divorce process embodied in the Act 1996 which professionals will have to manage .

The most obvious of the risks to victims of abuse is that their physical safety might be endangered during, as well as immediately before or after, appointments with professionals (for legal advice, for the preparation of welfare 


\section{Undercurrents of Divorce}

reports or for mediation). As a few highly publicised cases have revealed, a failure to protect clients from perpetrat ors of violence in these situations can have tragic consequences." Another opportunity for violence or intimidation may be created pursuant to the application of section 13 of the Act. This gives the court the power to direct parties, once a statement has been filed, to attend a meeting to be told the benefits of mediation. Research conducted in 1995-6 showed that, despite National Standards directing otherwise,' court welfare officers usually saw couples together at directions hearings, only $4 \%$ of officers always seeing parties separately (Hester et al, 1997, p.18).

In any event, the risks to victims of abuse are not confined to physical harm during or around encounters with professionals. The divorce process may prejudice the interests of abused spouses in a number of other ways. There is a risk that contact arrangements might jeopardise their safety,' that continued communication will perpetuate dominance and emotional abuse and that 'agreed' financial and property settlements would be detrimental to their interests. The practices of solicitors, mediators and family court welfare officers, both in report writing and mediation, can contribute to, or make less likely, such outcomes.

\section{Participating in Mediation}

The major concern in relation to divorce and domestic violence has been the anticipated greater use of mediation within the new legal framework for divorce. Parties are to be encouraged to attend mediation during information meetings, as well as during section 13 directions hearings and through the criteria for the award of Legal Aid. The benefits of mediation are widely extolled:

[Mediation] is seen by proponents and practitioners alike as more than a sensible strategy for settling disputed cases. It is said to be a civilised and civilising procedure, a process which returns to, or keeps control in, the couple, and a way of ensuring reliable arrangements for the future. As such it cannot be fully appreciated without consideration of such concepts as civility, friendship, trust and the pursuit of mutual interests (Walker et al, 1994, p.1).

Yet where violence or abuse has been a feature of the relationship between the couple, where the equality of power and control within that relationship is, as a result, doubtful and where trust may be non-existent, the benefits of mediation 
for the abused partner (and her children) are clearly thrown into question. As Shaffer puts it, 'mediation rests on the notion of two equally competent and effective negotiators, an idea which feminists point out does not conform to the reality of many male/female relationships' (1988, p.166). In cases of abuse, the divergence between the idea and the reality may be extreme.

Mediation services may be able to mitigate the effects of power imbalances by employing screening, coupled, in the cases they do take on, with support for the weaker party to enable her to bargain more effectively, and with constant monitoring for abusive behaviour (Ellis and Stuckless, 1996, pp.77$80)$. Mediation may even, provided it is voluntary, play a part in the reduction of 'postprocessing abuse' (Ellis and Stuckless, 1996, p.58). ${ }^{\circ}$ However, research suggests that mediation is inappropriate and even dangerous and abusive in cases where mediators do not ask about violence, do not have knowledge about the impact of violence, or lack the skill to deal with these issues (Young, 1996, in Hester et al, 1997, p.60).

\section{Leaving it to the Professionals}

We have observed that, while the Family Law Act 1996 contains provisions intended to reduce risks to victims of domestic violence, it also creates a divorce process that, with its marriage saving and child saving agendas, may increase their exposure to risk. Moreover, reflecting the dissent and the ambivalence expressed within the parliamentary debates, the statute contains no unambiguous message about the relative importance of protection. Dewar has recently argued that this 'chaos' in legislation impacting on the family is normal:

To put it another way, law more and more becomes the context in which those contradictions or oppositions that cannot be resolved politically are worked through. ... legislators have in fact created a set of inconsistent principles and commitments ... while at the same time using law to give the appearance of having created shared values; and then have off-loaded the detailed working out of those contradictions to the legal system (Dewar, 1998, p.484).

The contradictions and conflicting aims do not pose a threat to the functioning of family law, 'because [chaos] is held at bay by the practices of legal and other professionals associated with its day-to-day interpretation, application and administration' (Dewar, 1998, p.485). The task, therefore, of reconciling in 


\section{Undercurrents of Divorce}

practice the demands of child saving, marriage saving and spousal protection has, therefore, been left to the divorce professionals who may or may not, as the next section of this chapter is intended to reveal, have a clearer picture of domestic violence - individually or as a profession - than did the legislators.

\section{Professional Practice}

\section{Mediators}

Mediators may be accredited by various bodies. National Family Mediation (NFM), is the umbrella organisation for voluntary sector mediation which, together with the Family Mediators Association (FMA) and Family Mediation Scotland, now comprises the UK College of Mediators' which has issued a Code of Practice including guidelines in relation to domestic violence. ${ }^{22}$

Hester et al conducted a major survey of mediators working in the 59 NFM affiliated services in 1995. Few of their respondents said that their service had a screening policy $(1997$, p.43) and some were unsure whether they did or not. Moreover, only half of those who said their services did not have a policy thought it would be useful to have one. Hester et al categorised the practices of these mediators into safety oriented = an emphasis on always mediating' and 'non-specific' approaches. Only $11 \%$ of the responses could be categorised solely as 'safety oriented', the biggest category using the mixed, non-specific approach $\left(1997\right.$, p.36 et seq). ${ }^{2 x}$ The respondents who followed the safety-oriented approach would, for example, generally have separate initial meetings to screen for violence but only a handful of them believed that where domestic violence was known there should never be mediation. At the other end of the spectrum were those who took the view that mediation should always be tried and made little connection between issues of power and domestic violence (p.38). The 'non-specific' approach revealed a combination of elements from the other two.

The research also showed that, whilst $74 \%$ of respondents believed that violence would affect the balance of power in mediation and that techniques to address imbalance were necessary (p.47), these techniques did not always protect the abused spouse. Indeed, mediators sometimes exacerbated the victim's plight: 
In their attempts to appear 'fair' respondents were indeed likely to create dangerous situations for women. For instance, in their concern to 'equalise power' in domestic violence situations, a number of respondents, in effect, placed greater power and control in the hands of the male abuser, whom they saw as the 'real victim' or 'loser' in the situation ... One interviewee explained that once women leave violent men they are elated and feel empowered ... The men, on the other hand, are deflated, depressed ... (Hester et al, 1997, p.48).

These findings are cause for concern but they have been widely disseminated in order to promote change. Nevertheless it would be easy for individual mediators to slip through the training net: there is, after all, no legal requirement that mediators - unless working for services franchised by the Legal Aid Board are either accredited by one of the major organisations or trained in specific issues.

\section{Family Count Welfare Officers}

The picture of court welfare service practice revealed by Hester et al - in relation to mediation and the preparation of welfare reports - is more encouraging: there is evidence that it is more informed by an awareness of domestic violence, perhaps because court welfare officers are more likely to deal with difficult and conflicted cases.' Yet, of the 319 individual court welfare officers who returned a completed questionnaire, only $16 \%$ could be said to be adopting the 'safety-oriented' approach, with a further $7 \%$ of respondents fulfilling some of the 'safety-oriented' criteria (pp.12-13). The 'non-specific' approach was again the largest single group (26\%).

Court welfare officers who used a 'safety-oriented' approach were those who, for instance, took allegations of violence 'at face value ... acting as if such allegations were established fact', and reported accordingly (p.13). Those following the 'impartial report writing' approach, by contrast, took domestic violence into consideration in relation to safety but not necessarily in regard to outcomes. Those using an 'agreement-focused' approach mostly worked within a family therapy framework (p.14) ${ }^{z s}$ which might downgrade the factor of domestic violence.

Again service policies were not always known by individual officers (p.16) and screening was by no means routine, ${ }^{26}$ mainly being used once a welfare report was underway (p.15). The three main approaches used were inspecting files and court records, asking clients or relying on clients or other 


\section{Undercurrents of Divorce}

professionals to disclose abuse (p.15). As with the mediators, the belief of all court welfare officers that violence would increase the possibility of a power imbalance in mediation did not necessarily lead to a safety first approach: only a very small minority commented on the unsuitability of joint meetings in these circumstances (p.25). Nevertheless, $85 \%$ of respondents said they would challenge 'intimidating, controlling or undermining behaviour' to counteract the power disparity and $65 \%$ would ensure women received legal advice.

Again, practice may have changed since this research was carried out. In November 1996, the Association of Chief Probation Officers circulated national guidance designed to provide a starting point for the creation of more detailed local policies. It recommends that family court welfare officers use a 'screening schedule' and notes that it is generally inappropriate to see parties together or to refer them to mediation in cases of violence (paras 6.1 and 8.4).

\section{Solicitors}

Solicitors have not been subjected to a similar large scale survey in relation to domestic violence. We therefore draw on the small study conducted by researchers at Brunel University (see Piper and Kaganas, 1997). This used an interview sample of 36 solicitors selected from firms (in two geographical areas) with at least three partners and which claimed a family law specialism in the Law Society regional directories.' In addition, we ensured there were equal numbers of male and female solicitors, with just over half of them working in firms franchised by the Legal Aid Board for family law work.

The research aimed to illuminate solicitor practice in relation to divorce clients with children. We gave our interviewees a list of topics about which they might wish to seek information, and asked them to tell us, for each item, how routinely they sought such information. Twice as many solicitors said they 'sometimes' asked 'whether domestic violence was used or threatened' as said they 'always' asked. Furthermore, the use of transaction criteria did not ensure that franchised solicitors 'always' asked.

Although a relatively high proportion of solicitors in this study routinely enquired about domestic violence, we are concerned that many of these solicitors found knowledge about domestic violence only to be 'useful' in relation to establishing 'grounds' for divorce. In other words, their enquiries related to the completion of the divorce petition - a procedure which will become unnecessary under the new 'no fault' divorce law. Fourteen solicitors 
(almost $40 \%$ ) said they needed to know about violence if their client would have to rely on the 'unreasonable behaviour' fact and half of these mentioned no other reason for asking about domestic violence.

[I]f one is saying 'what are the grounds for divorce?' and one's looking at preparing a schedule of unreasonable behaviour one would of course say 'What's the problem? Wouldn't he wash his socks or did he beat you up everyday' [laughs] or something like that.

Not only does it arise when I go through the checklist but also it's brought out when I say 'Well, what's the reason for the breakup of the marriage? Is it another person or is it violence?'

On the other hand, half of the solicitors said or implied that information about domestic violence was useful for the purpose of protecting the client or the client's child. Of these 18 solicitors, $10 \approx$ referred explicitly to protection," while the remaining eight referred to it implicitly by mentioning, for example, 'the possibility of injunctions'. However, comments made by some of these solicitors when mentioning contact suggest that they might be thinking less in terms of the client's safety or freedom from intimidation and more in terms of domestic violence as an issue that compounds contact difficulties:

[O]ne parent might not want to have contact at all with the other - it's going to have repercussions for the fetching and carrying of children.

[P]eople are reluctant to have contact where the husband who's used physical violence in the past comes and collects the child from the home.

Moreover, almost half of the interviewees gave reasons that did not relate at all to their clients' welfare and just over half made no reference to children's

\section{Professional Pictures of Domestic Violence}

'They Will Tell Us'

It emerges from these studies that a significant proportion of solicitors, 


\section{Undercurrents of Divorce}

mediators and court welfare officers had not, by 1995-6, modified their procedures to take account of what is now known about domestic violence. One reason common to the three groups was the belief that clients who had experienced domestic violence would 'screen" themselves out' (Hester et al, 1997, p.58) or that 'domestic violence would always be raised by clients or their representatives if important' (p.17): 'they normally ring up and say "we want to have an appointment about domestic violence"' (a solicitor).

One in six of the solicitors we interviewed accounted for their reluctance to screen/ask all clients by stating that they were confident they could identify those clients who had suffered domestic violence: 'I don't ask the questions unless I start getting a smell'; 'You tend to gauge there's a situation when there might have been [domestic violence]'. For these solicitors, screening was a mental procedure based on instinct and experience rather than on explicit criteria.

A proportion of all three professional groups researched, therefore, had faith that they could sense whether clients were victims of domestic violence or that clients - or another professional - would tell them. No group had taken on the responsibility of finding out and none had routinised practice to do so. Two solicitors even appeared to think that routine questioning about domestic violence might be positively offensive because it would constitute 'a huge invasion of somebody's privacy'."

\section{'It Encourages A llegations'}

Comments made by mediators and court welfare officers echo fears expressed in the parliamentary debates and in the preceding consultation documents about encouraging false allegations of domestic violence. Hester et al report that court welfare officers were of the opinion that 'any emphasis on screening would only "invite" unnecessary and malicious allegations' (1997, p.17) and quote a mediator as saying: 'I would not like to see unsubstantiated allegations of domestic violence used as a way of distorting the process and sabotaging agreements' (1997, p.40). Despite the fact that Parliament has acknowledged the importance of taking account of domestic violence in the divorce process, professional thinking is often still influenced more by the pre-Act discourse, in evidence, for example, in the Consultation Paper:

[T] he objective here would be to separate the divorce process ... from other 
matters such as violence and molestation by removing the jurisdiction to grant injunctions for molestation and violence ancillary to divorce proceedings ... [otherwi-e] some separating partners might seek to exploit allegations of molestation and violence in order to avoid considering the merits of mediation (LCD, 1993, para 10.2). ${ }^{33}$

Protection from violence - though 'of vital importance'- should be a 'separate process' (para 10.3). Indeed, that document also gives the impression that petitioners may rely on the 'unreasonable behaviour' without any real substance: 'It is not difficult to obtain a divorce on intolerable behaviour' (para 5.2.); 'A finding of adultery or behaviour certainly need not mean the respondent is any more to blame than the petitioner for the breakdown of the marriage' (para 5.13); 'It is argued that the behaviour fact is particularly misleading. The behaviour need be neither unreasonable nor blameworthy' (para 5.18). The earlier Law Commission proposals included the same message: "In most divorces the spouses will both be "at fault" in varying degrees and it will be impossible to apportion responsibility for the breakdown' (Law Commission, 1988, para 3.16).

Of course, behaviour 'facts' cannot be equated with violence and, no doubt, there are cases where allegations are fabricated. But statements like the above help construct a story about divorce in which unfounded allegations are very common and in which parties are generally equally to blame. To some extent this divorce story deprives the victim's voice of legitimacy. In addition, it contributes to the ambivalence of those who have incorporated that tale into their knowledge base, and explains in part the shortcomings in professional practice in responding to domestic violence.

Mediators, in their future-oriented approach, also translate into practice the belief expressed in the Consultation Paper that the past should be left alone: 'Allegations of behaviour require the recollection of incidents which would best be forgotten ... A beginning of this kind is not constructive to the divorce process' (LCD, 1993, para 5.6). Hester et al refer to mediators who did not support routine screening for domestic violence for this reason:

They emphasised that they should have no knowledge about clients prior to the first mediation session, arguing that such knowledge would skew their perception of the individuals concerned and would compromise the 'neutrality' of their approach $(1997$, p. 58$)$. 


\section{Undercurrents of Divorce}

\section{Irrelevant Violence}

It appears that some professionals do not accord significance to violence or to violence of certain kinds. Where violence is judged mutual, for example, there is little need to protect one of the parties over and above the other. Similarly, it is assumed that violence ends on separation and that there is no risk to the victim afterwards. Hester et al report conflicting views about the mutuality or otherwise of inter-spousal violence and the effect on violence of separation. Twice the proportion of mediators as family court welfare officers believed that all domestic violence was mutual or 'as likely to be from women to men as from men to women' (Hester et d, 1997, p.41). ${ }^{34}$ Whilst this view was evident in the parliamentary debates,' it does not accord with the generality of research findings and contributes to a 'normalisation' of violence which diminishes professional motivation to implement pro-active policies in regard to domestic violence.

Some court welfare officers appeared to assume that violence ceases on separation: 'A few respondents did not consider screening for domestic violence relevant as it was no longer felt to be a problem once the partners had parted' (p.17). This view is clearly at odds with the picture from research and is one which feeds into the tendency to ignore the past.

Other reasons provided by court welfare officers reflect the dominance of the child saving strand in the divorce reform debates. If the violence 'concerned the adults and not the children' then screening was not important. What is more, it 'might prevent the possibility of agreement between the parties by precluding any joint meetings' (p.17). Here the aim of protection for abused spouses is subordinated - as it often was in Parliament - to the aims of marriage saving and conflict reduction (for the sake of the children and the Exchequer).

\section{Know le dge and Practice}

In the study by Hester et al there appears to be a correlation between wider definitions of violence given by court welfare officers and mediators and more safety-oriented practice (1997, pp.41-42 and 56-57). Similarly, in the Brunel study, the explanations of those solicitors who said they 'always' asked about domestic violence revealed the influence on their practice of knowledge about the prevalence of domestic violence and reluctance to disclose. Some solicitors appreciated that a client might 'feel awkward about coming out with it': 
And it's amazing - if you just, rather subtly, leave the question there then you'll get an answer - sometimes 'don't be stupid - we don't come from that part of town'. But amazingly it's sometimes quite surprising what does pop out [later you mean?] I'd always leave it ... just leave, give them an opportunity to say 'and I'm frightened of him' - for some reason or other. I always do that.

On the other hand, knowledge about prevalence did not automatically determine practice. As a solicitor commented: 'I wouldn't raise it unless they $\mathrm{did}$... Um - then I know they are frightening statistics with domestic violence but - urn - it's either relevant to the process or it's not, in my view' [emphasis added]. Professional imperatives can override concern. In the case of solicitors the need is to complete a divorce petition within the time available, in the case of court welfare officers the need is to give priority to the 'client' (the child), and, in relation to mediation, the need is to be seen as neutral and settlement oriented. It remains to be seen whether these professional imperatives will change or be outweighed as a result of the implementation of the Family Law Act 1996.

\section{Implications for the Implementation of a New Divorce Process}

\section{The Consequences of a No-Fault Law}

By removing the fault principle, the new law aims to eliminate the unfairness and resentment that is said often to accompany the public denunciation of one spouse by the other. Instead of exacerbating hostility, it is said, the divorce process should minimise it and reduce the trauma inflicted on children. This could be achieved by increased use of mediation (see LCD, 1993 and 1995).

The new law, then, is based on an assumption that divorcing couples are, generally speaking, able to behave reasonably and responsibly, to negotiate fairly and to co-operate in reaching satisfactory arrangements for the future. It was presumed that all that is needed is that couples be given the opportunity to do this and that mediation provides the key. However, the proposition that amicable resolution of disputes is unlikely where there is a history of violence or abuse was introduced into the story during the parliamentary debates. In Standing Committee, Mr Llwyd expressed his concern that there was 'precious little reference to violence in the Bill' (30 April 1996, col 92). 'There seems', he went on, 'to be more references to the word "amicably" than to domestic 


\section{Undercurrents of Divorce}

violence. In my experience, very few divorces are amicable ... By contrast, divorces that have come about through violence are prevalent' (idem). This alternative picture underpins the concern - within the higher echelons of professional bodies at least - to ensure the implementation of practices to remove the risk of abused spouses taking part in mediation or, alternatively, to diminish the risks attendant on doing so. Whether professionals of all 'ranks' will adopt such measures depends to a significant extent on which picture they have of domestic violence. It also depends on the message given to professionals about how the new legal provisions 'should' be used. Even if the picture of violence they hold changes to take account of issues such as separation violence and power imbalance, there are other factors that may continue to inhibit their adoption of more protection-oriented practice. These are the philosophy of conflict reduction and agreement that pervades divorce policy and practice as well as the prevailing images of 'good' parents and also 'good' lawyers.

\section{'Good' and 'Bad' Solicitors}

There is a consensus within the family justice system that legal remedies should be used as a last resort; the dominant welfare discourse precludes an adversarial, rights-based approach (see the final chapter in this volume). In addition, the original divorce reform proposals aimed to separate" domestic violence and the divorce process: it is difficult to sustain images of the good absent parent and of the child as victim of non-co-operative parents if violence is allowed to intrude (Piper, 1996). The prioritisation of mediation, the nonintervention principle in the Children Act 1989 and the stress on parental responsibility and co-operative parenting after divorce lead to two relevant outcomes. First, they place pressure on divorcing parents, particularly on mothers, to keep in contact with, talk to and co-operate with, a perpetrator of violence. Secondly, they constrain solicitors from activating legal provisions which might cause conflict. The strength or otherwise of these pressures and constraints will be a significant determinant of the successful implementation of section $1(\mathrm{~d})$.

As we have pointed out, many solicitors ask about domestic violence only to ascertain information necessary for the preparation of a divorce petition. With the removal of fault from the grounds for divorce a major impetus to seek out domestic violence is also removed and the impact of section 1 (d) on 
solicitor practice could be negligible.' It might also be negligible at other stages of the process. For example, there is no statutory requirement (as there is to be on mediators franchised by the Legal Aid Board) to screen for domestic violence at section 13 directions hearings and neither are there any statutory duties imposed on privately funded mediators. Solicitors, mediators and court welfare officers would need to routinise screening if abused spouses are not to fall through the net at that point. They also need clearer guidance to the effect that protection from violence should take precedence over other aims. Even $\mathrm{Mr}$ Boateng, in supporting the amendments concerned with protection, went only so far as to state that, while it was right for Parliament to send a message about the value of the institution of marriage, it was 'equally right that Parliament should send out a message about the value and importance of maintaining a home environment free from violence' [emphasis added] (Standing Committee E, 7 May, col 117).

Indeed, it may be that parliamentarians did not anticipate that section 1(d) would have a significant impact on practice; doubts were expressed as to whether it would 'materially affect the operation of the legislation' (Standing Committee E, 7 May, col 101). There are, however, other provisions relating to domestic violence which could furnish an impetus for change, provided that a professional consensus emerges that the need to protect from violence and its effects trumps the current professional imperative to avoid conflict and the use of courts. One solicitor involved in the Brunel research felt unable to ask about domestic violence unless 'legally' he had to do so.' Section 1(d), if 'promoted' by the LCD and by professional bodies could provide such a catalyst but it is more likely that role will be played by sections $7(12)$ and $9(7)(d)$, read with schedule 1, para 4. If solicitors assume that it is in their client's interests to keep the period for reflection and consideration to the minimum, they may routinely enquire about domestic violence to see if there are grounds for the nonmolestation or occupation order which preclude the extension of that period. Similarly, solicitors may ask about violence if they consider it important to ensure that their clients will be able to get an order even if the financial arrangements are not settled. The use of these provisions could lead to more, not less, litigation, but could uncover more domestic violence and protect more family members.

Whether they will do so, as we have pointed out, will depend on a complex web of factors: the way the professional picture of domestic violence now evolves, the strength of guidance about priorities and aims for those 
operating the new divorce process, the amount and type of legal advice to be state funded and the influence of particular ideas about the welfare of the child and the family. In this area at least, there is room for optimism that the legislative 'chaos' - which to some extent became apparent during the passage of the Family Law Act 1996 - will be resolved in a way that provides greater protection for those subject to domestic violence.

\section{Notes}

1. See also section $4(5)(a)$.

2. The duty to do this is placed on 'the court and any person, in exercising functions under or in consequence of Parts $\Pi$ and II', in other words all lawyers, probation officers, social workers, mediators and Legal Aid administrators, inter alia.

3. Ruth Deech, The Times 22 March 1996, quoted in Hansard, Standing Committee E, HC 7 May 1996, col 95).

4. See als o Hansard, I-IL 27 June 1996, cols 1069, 1092.

5. The 12 month period is now made up of the 9 month period of reflection and consideration and the 3 month period between attendance at an information meeting and the making of a statement of marital breakdown. See Hansard, HC 17 June 1996, col $604 \mathrm{ff}$. See, for a review of the history of section 7, Cretney and Masson (1997) p.349, n.15.

6. Some concerns were expressed about the effects of delay on wives who are victims of domestic violence. However, these did not appear to extend to the minimum period (see Hansard, HC 17 June 1996, cols 608-609; HL 27 June 1996, col 1066).

7. Giving, as an example of such behaviour, a woman making great play of the sexual impotence of her partner.

8. See Hansard, HC 17 June 1996 , col 600.

9. See also Ingleby (1992).

10. See Mayhew et al (1993, p.98); Mirrlees-Black et al (1996); Mooney (1994); Polk (1994); Stanko et al (1998).

11. See also Polk (1994) on separation violence.

12. See Kaganas and Piper (1994) p.268; Ellis and DeKeseredy (1997); DeKeseredy and Macleod (1997); Sev'er (1997).

13. See, for example, the Guardian article by Beatrix Campbell (1996).

14. See also Hester et al $(1997$, p.9). Ellis and Stuckless identify three types of violence: conflict- instigated, control-instigated and anger-ins tigated. While all three types may be intermingled behaviourally, it appears that men are more likely to engage in both control-instigated violence and in serious conflict-instigated violence (1996, pp.42-46).

15. As the White Paper does (LCD, 1995 para 5.29).

16. The safety of professionals too might be endangered when dealing with violent clients. Examples of such cases are provided by Wardle (1994, pp.743-744). 


\section{Divorce and Domestic Violence 203}

17. One such incident is referred to by a mediator in Hester et al's research (1997 pp.4647).

18. See the National Standards for Probation Service Fan ily Court Welfare Work (Home Office, 1994, para 4.13).

19. See Hester and Radford, 1996.

20. Ellis and Stuckl ess suggest that mediation makes a greater contribution to reducing abuse than lawyer negotiation because of the use made by lawyers of affidavits containing hurtful allegations $(1996$, p.58).

21. There are other mediation trainers in existence or proposed, for example BALM (British Association of Lawyer Mediators) and the Law Society.

22. See Hester et al (1997, Appendix D) which reproduces the most recent guidance for screening for abuse, for deciding whether to terminate or proceed with mediation if abuse is discovered (sections $\mathrm{A} 3$ and $\mathrm{A4}$ ) and for practice where mediation does take place despite knowledge of abuse (section A5).

23. $29 \%$ 'always mediated', while sixty percent of respondents adopted the mixed approach.

24. Hester $e t$ al note that 'court welfare officers talked of up to $90 \%$ of their case load as involving violence' $(1997$, p. 7 ).

25. It is not entirely clear what this entails but, if a therapeutic approach based on family systems theory is used, and violence is attributed to intra-family interaction, welfare officers might be failing to take account of control-instigated abuse (see Ellis and Stuckless, 1996, pp.30-34).

26. Only $14 \%$ of respondents screened their clients at whatever stage of the process they were dealing with them (p.17) though half of the remainder thought the use of screening should be extended.

27. Half the interviewees worked in a court area which had a high rate of section 8 private law applications and half in an area with a low rate of applications. (See Children Act Advisory Committee Annual Report 1992/93 (Lord Chancellor's Department, 1993, pp.94-95), based on the period June 1992 - June 1993). The 'high' area had around 30 applications per 10,000 of the population compared with around 10 in the 'low' area and an average of 21.3 for England and Wales as whole. Because of their geographical locations these are referred to as the Northern (high rate) and Southern (low rate) samples.

28. Questioning in relation to the use of the unreasonable behaviour fact is significant for disclosing abus e given that, in England and Wales in 1994, 54\% of all decrees granted to wives rely on unreasonable behaviour as the fact proven (and $71 \%$ of all decrees granted to one party - that is, excluding divorces awarded in response to joint petitions were granted to wives): Haskey, 1996.

29. All of whom worked in franchised firms and seven of whom said they always asked about domestic violence.

30. One solicitor referred specifically to its relevance to advice on attendance at mediation: Tor example, if I suggested mediation and she said "There's no way I'm going to mediation" then I would ask about the possibility of domestic violence'.

31. $\quad 15$ and 19 solicitors respectively. 


\section{Undercurrents of Divorce}

32. Solicitors who participated in the research were invited to seminars (in 1997-8) to discuss the results. Individual solicitors in both areas still expressed their inability to ask questions about domestic violence unl ess they 'needed' to.

33. Those who responded to the Consultation Paper were also 'particularly concerned about the possibility of petitioners making all egations of fault that were exaggerated or uncorroborated' (LCD, 1995 para 2.28).

34. This is a stance which gains support from research using the Conflict Tactics Scale (CTS) which, in its more simplistic versions, ignores the reas on for violence (see Kurz, 1996, p.72). The notion that domestic violence is a contest between equals is often criticised as being based on a failure to distinguish between acts of aggression and selfdefence; a failure to dis criminate adequately between different types of violence; and a failure to take account of the effects of an act or the severity of any injuries caused. It ignores issues of dominance and control and renders disparities in power and vulnerability invisible. See, for example, for critiques of the 'family violence' approach to research on domestic viol ence, Dobash and Dobash, 1992a; Dobash and Dobash, 1992 b; Kurz, 1993.

35. As a Conservative MP express ed it: 'perhaps as part of the movement towards greater equality ... there has been a considerable increase in the amount of violence perpetrated by women as well' (quoted in ROW, 1996, p.9).

36. Increasingly, links are being made between the abuse of mothers and harm to children (Mullender and Morley, 1994; Hester and Radford, 1996). However, as Behrens says, 'a woman should not have to argue for her safety based sol ely on the best interests of the child' (1996, p.43). See also Graycar (1995, p.69).

37. See Neale and Smart, 1997.

38. As Smart has recently pointed out (1997, p.312), even the important sociological work of Giddens on 'confluent love' contributes to perpetuating the invisibility of 'violence, bullying, economic deprivation and various forms of cruelty ... [because] these grimmer elements of married life and intimate relationships do not occupy much of the analysis'.

39. This should not be read as a plea for the resurrection of the old fault-based system. Nor should it be read as affording any support to the arguments recently put forward by Wardle (1994) to the effect that no-fault divorce culture fosters violence. For a text which is in contrast to the official discourse of divorce see Whelan (1995).

40. Some members of parliament had anticipated this outcome: doubts were expressed as to whether it would 'materially affect the operation of the legislation' (Stan ding Committee E, 7 May col 1010).

41. Participant at the follow-up seminar held in the northern area on 15 July 1998.

\section{References}

Anders on, L. (1997), 'Contact Between Children and Violent Fathers - In Whose Best Interests?' Rights of Women, Bulletin, Summer.

Association of Chief Officers of Probation (1996), Guidance to Area Probation Services on Fam ily Court Welfare Service and Domestic Violence, ACOP, London. 
Astor, H. (1991), Position Poper on Mediation, Prepared for the National Committee on Violence Against Women, Commonwealth of Australia.

Barron, J. (1990), Not Worth the Paper..? The Effectiveness of Legal Protection for $W$ amen and Children Experiencing Domestic Violence, WAFE Ltd, London.

Behrens, J. (1996), Ending the Silence, But ... Family Violence under the Family Law Reform Act $1995^{\prime}$, Australian Joumal of Family Law, vol 10, pp.35-47.

Borkowski, M., Murch, M. and Walker, V. (1983), Marital Violence: The Community Response, Tavistock, London.

Campbell, B. (1996), 'Big Bad Dad', Guardi an 25 June.

DeKeseredy, W. and Macleod, L. (1997), Wom an Abuse: A Sociological Story, Harcourt Brace, Toronto.

Dewar, J. (1998) 'The Normal Chaos of Family Law', Modern Low Review, vol 61(4), pp.467485.

Dobash, R.E. and Dobash, R.P. (1992a), Women, Violence and Social Change, Routledge, London.

Dobash, R.E. and Dobash R.P. (1992b), The Myth of Sexual Symmetry in Marital Violence', Social Problems, vol 39, p.71.

Ellis, D. and DeKeseredy, W. (1997), Rethinking Estrangement, Interventions and Intimate Femicide', Violence Against Women, vol 3, pp.590-609.

Ellis, D. and Stuckless, N. (1996), Mediating and Negotiating Marital Conflicts, Sage, London.

Fischer, K., Vidmar, N. and Ellis, R. (1993), 'The Culture of Battering and the Role of Mediation in Domestic Violence Cases', SMU Law Review, vol 46(5), pp.2117-2174.

Graycar, R. (1995), 'The Relevance of Violence in Family Law Decision Making', A ustralian Joumal of Family Law, pp.58-69.

Haskey, J. (1996), Divorce Statistics', Fanily Law, p.301.

Hester, M. and Radford, L. (1996), Domestic Violence and Child Contact Arrangements in England and Denmark, Policy Press, Bristol.

Hester, M., Pearson, C. and Radford, L. (1997), Dom estic Violence, A National Survey of Count Welfare and Voluntary Sector Mediation Proctice, Policy Press, Bristol.

Home Office (1994), National Standards for Probation Service and Fam ily Count Welfare Work, Home Office, London.

Hooper, C. (1996), 'Men's Violence and Relationship Breakdown: Can Violence be Dealt with as an Exception to the Rule?', in W omen \& Social Policy. An Introduction, C. Hallett (ed), Harvester Wheatsheaf, Hemel Hempstead.

Ingleby, R. (1992), Solicitors and Divorce, Clarendon Press, Oxford.

JRF (Joseph Rowntree Fund) (1997), Findings: Social Policy Research 117, JRF, York.

Kelly and Radford (1990/1), Nothing Really Happened: The Invalidation of London Women's Experiences of Sexual Violence', Critical Social Policy, vol 10(3), pp. 39-53.

Kurz, D. (1993), 'Social Science Perspectives on Wife Abuse: Current Debates and Future Directions' in P. Bart and E. Morgan (eds), Violence Against Women: The Bloody Footprints, Sage, London.

The Law Commission (1988), Facing the Future. A Discussion Paper on the Ground For Div arce, Law Com. No. 170, HMSO, London.

Legal Aid Board Annual Reports 1995-6 (1996), HMSO, London. 


\section{Undercurrents of Divorce}

LCD (Lord Chancellor's Department) (1993), Looking to the Future, Mediation and the Ground for Divorce, Consultation Paper, Cm 2424, HMSO, London.

LCD (Lord Chancellor's Department) (1995), Looking to the Future, Mediation and the Ground for Divorce, Cm 2799, HMSO, London.

Mahoney, M. (1991), Legal Images of Battered Women: Redefining the Issue of Separation', Michigan Low Review, vol 90, pp.1-94.

Mahoney, M. (1994), 'Victimization or Oppression? Women's Lives, Violence and Agency', in M. Fineman and R. Myktiuk (eds), The Public Nature of Private Violence. The Discovery of Domestic A buse, Routledge, New York, London.

Mayhew, P., Maung, N. and Mirrlees-Black, C. (1993), The 1992 British Crime Survey, HMSO, London.

Mirrlees-Black, C., Mayhew, P. and Percy, A. (1996), The 1996 British Crime Survey, England and $W$ ales, HMSO, London.

Mooney, J. (1993), The Hidden Figure: Domestic Violence in North London, Centre for Criminology, Middlesex University.

Morley, R. (1993), 'Recent Responses to "Domestic Viol ence" Against Women: A Feminist Critique', Social Policy Review, vol. 5, p.177.

Mullender, A. and Morley, R. (eds) (1994), Children Living with Domestic Violence: Putting Men's Abuse of Women on the Child Care Agenda, Whiting and Birch Ltd, London.

Office of National Statistics (1997), Marriage and Divorce Statistics, England and Wales 1994, Series FM2, No. 22, HMSO, London.

OLeary, K., Neidig, P. and Heyman, R. (1995), 'Assessment and Treatment of Partner Abuse: A Synopsis for the Legal Profession', Albany Low Review, vol 58, pp.1215-1233.

Pagel ow, M. (1990), Effects of Domestic Violence on Children and Their Consequences for Custody and Visitation Agreements', Mediation Quarterly, vol 7(4), pp.347-363.

Piper, C. and Kaganas, F. (1997), 'The Family Law Act 1996 sl(d): How Will "They" Know There is a Risk of Violence?', Child and Family law Quarterly, vol 9(3), pp.279-89.

Piper, C. (1996), 'Divorce Reform and the Image of the Child', Joumal of Low and Society, vol. 23(3), pp.363-382.

Polk, K. (1994), When Men Kill. Scenarios of Masculine Violence, Cambridge University Press, Cambridge.

Rights of Women (ROW) (1996) Bulletin, Summer.

Sev'er, A. (1997), Recent or Imminent Separation and Jntimate Viol ence Against Women', Violence Against Women, vol 3, pp.566-589.

Shaffer, M. (1988), Divorce Mediation: A Feminist Pers pective', University of Toronto Faculty of Low Review, vol. 46(1), pp.163-200.

Smart, C. (1997), 'Wishful Thinking or Harmful Tinkering? Sociological Reflections on Family Policy', Joumal of Social Policy, vol. 26(3), pp.301-321.

Stark, E. (1995), Re-Presenting Woman Battering: From Battered Woman Syndrome to Coercive Control', Albany Low Review, vol 8, pp.973-1026.

Stanko, E., Crisp, D., Hale, C. and Lucraft, H. (1998), Counting the Costs: Estim ating the Impact of Domestic Violence in the Borough of Hackney, Crime Concern, London.

Walker, J. McCarthy, P. and Timms, N. (1994), Mediation: The Making and Re-making of Cooperative Relationships, Relate Centre for Family Studies, Newcastle University. 
Wardle, LD. (1994), Divorce Violence and the No-Fault Divorce Culture', Utah Law Review, pp.741-775.

Whelan, R. (ed) (1995), Just a Fiece of Paper? Divorce Reform and the Undemining of Marriage, Institute of Economic Affairs, London.

Young, K. (1996), Research Evaluation of Family Mediation Practice and the Issue of Violence, Attorney-General's Department, Australia. 